\section{Towards establishing a Constellation of States in Southern Africa}

\section{Harry Oppenheimer}

Chairman, Anglo American Corporation of South Africa

Speech delivered at the opening of the South African Pavillion at Milner Park, Johannesburg on April 21980

I received the invitation to open this exhibition with great pleasure and I must confess with not a little surprise. It is not, I think, usual for private businessmen to be asked to open Government exhibitions, and that the private businessman chosen on this occasion should be me is surely something that, say, eighteen months ago would have been almost inconceivable. It is obvious that l owe this honour - an honour which I very much appreciate - to the new relationship between the Government and the private sector of the economy which was signalled by the Prime Minister's meeting with leading businessmen in Johannesburg in November last year.

The concept of a Constellation of States in Southern Africa is a stimulating one and it was an excellent idea to devote this exhibition to its presentation and elaboration. Up till now this phrase 'a constellation of states' has remained little more than a phrase - a glowing metaphor which can mean many different things to different people. And indeed no-one, I think, could reasonably expect the Government to express it at this early stage in a definite programme of action. It is still in the nature of a 'ballon d'essai' intended to provoke thought and discussion both within the country and outside our borders. To that end this exhibition will, I am sure, be very useful; for if this new initiative of the Government is to bear fruit it is certainly high time that it should be considered in more detail and more closely defined.

At the Prime Minister's meeting with businessmen to which I have already referred, I expressed the opinion, which the Prime Minister was kind enough to endorse, that no constellation of states would succeed it if were to be conceived as a fortress or laager in a hostile world. It should, on the contrary, be thought of as part of an open door policy, both economically and politically, and as a means of improving our relations with our neighbours in Africa and with the great democracies of the Western world whom we would like to be able to think of as our friends. This is not going to be easy.

President Kaunda, of Zambia, has recently held a conference of Southern and Central African States in Lusaka with the object apparently of forming a different sort of constellation from which we in South Africa would be excluded. Economically such a concept could not possibly hope to succeed. No economic grouping of Southern African States could afford to exclude the most powerful and most highly developed country in the area; and what President Kaunda, so it seems to me, is really saying is that unless South Africa is able to improve its relations politically with the black states of Africa, the economic unity which all recognize to be necessary will only be brought about over a long period of conflict and of suffering. Nor can we escape the problem by limiting our constellation to the Republic and those new states that have been carved out of the Republic. That surely would be altogether too unambitious a project; and would, anyhow, be more properly characterized as a satellite system rather than a constellation.

Obviously the establishment of normal relations with our black neighbours implies goodwill from both sides. I am, however, optimistic enough to believe that our Government's new policy, if it is honestly and urgently pursued, will meet with the response which it deserves from Black Africa.

\section{What needs to be done}

What is it that we need to do? Externally it is plain that the first need is to find a satisfactory solution to the question of South West Africa/Namibia; to find a way in which fair elections can be held in that territory, and international recognition secured for the Government which is chosen by the people. In this regard the latest reports we have received are a cause at once of anxiety and hope.

Internally we have to make a reality, within as short a period as is practical, of the Government's announced policy of eliminating racial discrimination from the law and life of Southern Africa. What does this imply? First and foremost I would say that it means education for blacks not inferior to that available for whites; secondly, it means the end of the pass laws in their present form; thirdly it means decent housing and security of tenure for all blacks in the urban areas; fourthly, equal opportunities for blacks with whites in the business of the country and in the professions; and fifthly a proper share in political power for all our black population, not only for that part of it which lives in the homelands.

We have a long long way to go in each of these respects; and no sensible person can expect the discriminatory effects of three hundred years of white domination in South Africa to be abolished with the wave of a wand. What is necessary now, however, and what to my mind is now practical, is to translate the policy that has been announced in general terms by the Prime Minister and his colleagues into a programme of action, and so far as is possible (and here we must not expect too much) to attach to that programme an indicated timetable.

This is the background to the establishment of relations with our neighbour states such as are necessary for making a positive success of the great concept of a Southern African Constellation.

\section{Focusing on factors bringing people together}

The end of the colonial empires and the emergence of numerous independent African states, together with our Government's own independent homeland policy, have served to emphasize the cleavages, tribal, social, linguistic and political which so deeply divide Southern Africa. But now it is time to focus a spotlight on the factors that bring the peoples of Southern Africa together. 
And of these the need for economic development and the elimination of poverty, hunger and disease comes first to mind. But equally important is the need to build in Southern Africa an international organization in which the constituent states can feel secure against external aggression or interference, and in which the Government of each of them is pledged to social justice and to protecting freedom of choice, political and economic, and the individual dignity of all people regardless of race, creed or sex. This as I see it is the ideal which lies behind the concept of a constellation of states and which makes it a real plan for peace and progress, not just an attractive astronomical metaphor.

In what I have said I have perhaps put too exclusive an emphasis on what we must expect of the Government. Obviously it is the Government which must give the lead; but a great responsibility rests also on private individuals, and in particular 1 would say on the leaders of the business community. Perhaps it was in order to emphasize that point, that I was honoured with the invitation to open this exhibition. If so I would regard the invitation with still greater pleasure.

South Africa is moving forward into a new era: Inevitably in this period of rapid change we are going to make mistakes. But let us, if possible, learn from history - particularly I would say from history of the last thirty years - and try to ensure that the mistakes we make have at least the merit of being new mistakes; and when we fail, as we certainly shall from time to time, let us at least try to ensure that we do not fail for lack of good will to any of our peoples, black, white or brown.

\section{Boekresensie}

\section{Die taak van die bemarkingsbestuur}

\author{
Dr. P.J. Kieser \\ (J.L. Van Schaik Beperk Pretoria) \\ Eerste Uitgawe 1979 \\ (pp 900) \\ Prys: R18,00
}

Dr. P.J. Kieser, Algemene Bestuurder, SAFTO, Johannesburg

Hierdie boek is opgedra aan proff F.E. Rädel en H.J.J. Reynders uit erkenning vir die pionierswerk wat hulle verrig het met die opstelling van die boek 'Inleiding tot die Bedryfsekonomie'.
Die hulde wat hier gebring word aan twee groot leermeesters op die gebied handel en bedryfsekonomie is beslis nie onvanpas nie. Die boek onder bespreking is net soos sy voorganger, die produk van 'n spanpoging, waar 'n patroon van samewerking tussen Afrikaanse universiteite daargestel is.

Met die verskyning van 'Die taak van die bemarkingsbestuur' het ons ' $n$ waardevolle toevoeging gekry tot ons vakliteratuur in 'n reeks wat op voltooiing wag. Dit sal gebeur wanneer derglike werke oor onderwerpe soos produksie, administrasie en personeelbetrekkinge die lig sien. Hierdie hoop word ook deur Rädel en Reynders in 'Inleiding tot die bedryfsekonomie' uitgespreek.

Die taak van die bemarkingsbestuur het duidelik en baie goed daarin geslaag om die breë terrein van bemarking en bemarkingsbestuur so volledig moontlik op 'n geordende en logiese wyse te boek te stel. Ons het nou in Afrikaans ' $n$ duidelike samevatting en 'n gesaghebbende uiteensetting van die terme en begrippe van dié afdeling van die bedryfsekonomie; ' $n$ boek waarna almal: akademici en studente, praktiserende bemarkers en belangstellende leke kan verwys om op hoogte te kom van die fundamentele begrippe van dié vakterrein. Hierin slaag die boek besonder goed, en die redakteurs en medewerkers moet hierme gelukgewens word.

'Die taak van die Bemarkingsbestuur' bestaan uit vyf dele en 33 hoofstukke.

- Deel 1 bestaan uit ' $n$ terreinverkenning en inleiding oor bemarkingsbestuur.

- Deel 2 gee 'n oorsig van die omgewing waarin die bemarkingsbestuur optree met spesifieke verwysing na die Suid-Afrikaanse situasie wat dié werk se waarde baie verhoog.

By die bespreking van die mark en verbruikersgedrag word daar heel toepaslik van Suid-Afrikaanse statistiek gebruik gemaak om bemarkingsbeginsels sinvol toe te lig.

- In Deel 3 volg 'n deeglike uiteensetting en omskrywing van die hulpmiddels waaroor die bemarkingsbestuurder beskik. Bemarkingsinligtingstelsels word breedvoering bespreek ( $\mathrm{Hfst} 6$ ) en die onderlinge verband tussen bemarkingsnavorsing en bemarkingsinligtingstelsels word in Hfst 7 uitgewys.

Die beplanning en uitvoering van 'n bemarkingsondersoek word ook volledig behandel.

Hoofstukke 8 en 9 verskaf baie bruikbare tegnieke oor markmeting en markvooruitskatting, asook marksegmentering en doelmark keuse.

Die hooftema van die boek, naamlik die taak van die bemarkingsbestuur, word volledig in Deel 4 behandel.

Al die bemarkingsbeleidsinstrumente, bemarkingsorganisasie, koördinasie en beheer word logies en beredeneerd in hoofstukke 10 tot 16 uiteengesit.

- Deel 5 volg laastens met 'n bespreking van enkele gespesialiseerde bemarkingsterreine, soos die bemarking van:

- kapitaaltoerusting

- landbouprodukte

- kommersiële dienste

- kleinhandelsdienste en -goedere 